\title{
The Russian Telecommunications Experience: a Positive Outcome of the Competitive Order in the Industry
}

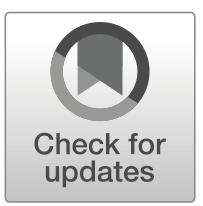

\author{
Dmitrii Trubnikov ${ }^{1,2}$
}

Received: 23 September 2018 / Revised: 29 March 2019/

Accepted: 2 April 2019 / Published online: 24 April 2019

(C) The Author(s) 2019

\begin{abstract}
The assumption that the telecommunications industry has natural monopoly characteristics dominated industrial policy during the twentieth century, supporting the monopolistic structure of telecommunications markets all across the world, and still prevails in many views on the economy of this field. The high level of concentration of telecommunications markets is often considered as a natural way of its development and some claim that this is a necessary condition for innovations in the industry. Meanwhile, the evolution of telecommunications in Russia after the collapse of the Soviet Union has shown quite the opposite. The industry in the country was able to demonstrate a relatively low level of market concentration, at least in some of the areas, to provide a high quality and a large variety of telecommunications services at significantly lower prices, in comparison with western countries, and shows one of the best indicators of network development in the world. While the Russian case poses quandaries for mainstream theories, the phenomenon fits the view of the Austrian school at the market process and exposes the benefits that the competitive order can bring to society.
\end{abstract}

Keywords Telecommunications · Regulation · Competition · Competitive order - Market process · Innovation

JEL Classification L51 L96 B B53

\section{Introduction}

The telecommunications industry has been considered as an example of a natural monopoly over the major part of the twentieth century. Even when the pro-market ideas penetrated

Dmitrii Trubnikov

d.trubnikov@uvt.nl

1 Tilburg Institute for Law, Technology, and Society (TILT), Tilburg University, Tilburg, Netherlands

2 Department of Economics and Management, Immanuel Kant Baltic Federal University, Kaliningrad, Russia 
industrial policy during the last decades of the century, the understanding that not all layers of the industry are able to have a competitive form governed the "liberalization" process and was expressed in a new regulatory environment, a new role of the state in the industry's development, and different methods of promotion of rivalry through regulatory tools. At the same time, the biggest telecommunications market of Europe, the Russian Federation, since the collapse of the Soviet Union, has demonstrated comparatively low level of concentration in many of its parts without any attempts to promote competition at all. The industry in Russia has been a place for the introduction of a number of innovative solutions by local and regional market actors despite weak state institutions, a high level of corruption, and an industrial policy that has been hostile for independent innovative activity. Russian telecommunications have showed one of the best figures of development of fiber-optic networks in the world in spite of the absence of essential government support of its construction.

Joseph Stiglitz (1999) even notices that Russian telecommunications pose "quandaries for traditional economic theories." However, it is not entirely clear whether some features of the Russian market distinguish it from the other examples that have been explained by the economic mainstream, or the mainstream theories have been based on fragile assumptions, that, in turn, had been the result of the previous ways of the industry development under the close supervision of the states all across the world. At the same time, if we look at the phenomenon from positions of the Austrian school, we will see that the case supports the theoretical propositions about competitive order and dynamism of the market process. The Russian experience, where the industry to a large extent was left to itself for several years in the beginning of the reform, demonstrates how market forces were able to govern the development of the field without close supervision of the state, and that makes the case particularly interesting for analysis.

The article begins with a review of the contrast between the "competitive order" paradigm and the actual "ordered competition" regime adopted by industrial policy around the world. This part also highlights the cross-countries differences with a particular attention to the fact that some territories that are among the world leaders of the telecommunications network development have not relied in this development on state aid and regulation, and introduces the Russian telecommunications industry as a remarkable example of this kind. Section 3 is dedicated to the initial stages of the market reforms in the industry in Russia and explanation of the peculiarities of privatization of telecommunications in the country that allow to claim that the process in Russia was much closer to the Austrian view at "spontaneous privatization" than the European "state-led privatization" approach. The fourth section analyses the evolution of the order of the telecommunications industry in Russia. This section is constructed around the timeline of the industry development linked to the milestones of the transformation of the former Soviet monopoly and provides the main argumentation of the research. The empirical examples of this part explain how and why the decentralized industrial structure and independent entrepreneurship are able to satisfy actual social needs, while interventions in the market process tilt the industry towards concentration with negative consequences for its development.

\section{2 "Competitive Order" vs. "Ordered Competition" in Telecommunications}

The period, which might be considered as a period of "deregulation" of telecommunications, started in different parts of the world during the last decades of the twentieth century. Despite 
the common use of the term "deregulation," the state has not retreated from the industry and has continued to play an important role in the field. Industrial policy has adopted a course on the promotion of competition and stimulation of investment and innovation, and one of the major challenges that arose before the policymakers was, on the one hand, to open the doors of the industry for newcomers and to enable consumers to benefit from the diversity of the services and low rates, but, on the other hand, the policy should not discourage market participants from the development of their networks. Cambini and Jiang (2009), for example, remark that " $[\mathrm{t}]$ he tension between promoting competition and promoting investment has been noted widely in the telecommunications economics literature."

Since the industry had long been recognized by the mainstream as an example of a market with natural monopoly characteristics, the opportunity for competition was initially sought only in some parts of telecommunications, while others remained under the control of incumbents (Yoo 2011). Meanwhile, Spulber and Yoo (2013) point out that there has not been agreement among empirical scholars about subadditivity of local telephone services. Faulhaber (2003) complains that "the "natural monopoly" thesis ... was never actually put to a market test," and some scholars even claim the mainstream declaration "that free-market competition was the source of the telephone monopoly in the early twentieth century is the biggest lie ever told by the economics profession" (DiLorenzo 1996). ${ }^{1}$

The "natural monopoly" paradigm, supported by the aims "to avoid inefficient investments duplications" (Cambini and Silvestri 2013) and, at the same time, by the objectives to promote market mechanisms in the field, influenced industrial policy at the initial phase of "liberalization" and expressed in the idea of fostering service-based competition depended on the mandatory access to the incumbents' infrastructure (Yoo 2011). This approach has been widely adopted in EU regulatory policy, but, nowadays, the growing body of the literature dedicated to the analysis of the connection between industrial policy and development of telecommunications networks points out that the countries where efforts on promoting servicebased competition were more successful show lower indicators of development of the socalled next-generation access (NGA) networks. For example, Briglauer and Gugler (2013) argue that the EU regulatory framework is likely to lower investment in NGA infrastructure, while Yoo (2014) explicitly points out that the European approach had a negative effect on the broadband investment. The claims that regulated cost-based access charges to incumbents' facilities reduce the investment incentives for incumbents, as well as, for new entrants might be found in a number of contemporary studies of the field (e.g., Jorde et al. 2000; Cambini and Jiang 2009; Yoo 2011; Crandall et al. 2013).

As an alternative to the European approach, modern telecommunications researchers often distinguish either a US "market-driven" strategy, or an Asian model, where the states actively participated in the development of the networks (e.g., Cambini and Jiang 2009; Briglauer and Gugler 2013). The Russian case, which is analyzed in the present paper, on the one hand, has some similarities with the US model because market forces have played a major role in the development of the field, but the totally different institutional environment, starting points, and the pace and trajectory of the evolution of the industry, on the other hand, put the Russian example into a separate category. Moreover, it is interesting to notice that according to various studies, the rollout of NGA networks in Russia outperformed the North American

\footnotetext{
${ }^{1}$ This claim is mainly addressed to the use of the term "natural" because monopolies of the telecommunications markets have rather been an outcome of political decisions than natural market forces (see also, e.g., Mueller 2013; Janson and Yoo 2013)
} 
telecommunications sector (e.g., Briglauer and Gugler 2013; FTTH Council Europe 2012, 2016), and if in both cases the industry has been mainly governed by the market rather than by regulation, then it is also possible to argue that the competitive order of Russian telecommunications was, at least until quite recently, more efficient than the US marketplace.

The discourse dedicated to the competitive order, and especially in the interpretation of the Austrian school, points out one crucial caveat that is noticeably ignored by the modern mainstream economic theories and by the regulatory policy, which, according to its proclaimed objectives, aims to increase competition in the modern economy. This warning was raised by Hayek when he contrasted the ideas of "competitive order" and "ordered competition," and the problem lays in different understanding of the nature of competition. While the mainstream theoretical models have been historically based on the concept of perfect competition, and for them deviation of a market from this fundamental premise signifies existence of a market failure problem, and, thus, justification for intervention; there are reasonable claims that the model of perfect competition is conditions where competition is totally impossible, ${ }^{3}$ and, thereby, this is not only an undesirable, as well as impossible, situation from the social needs perspective, this is also one of the main theoretical drawbacks that leads to a choice of wrong policies (Hayek 1949a; see also Kirzner 2000; Littlechild 2018).

When the last decades of the twentieth century yielded a surge of "liberalization" in various spheres of our economy, the "non-orthodox" liberal camp also provided its proposals for the reforms. Stephen Littlechild, whose "economic-philosophical background" can be linked to the Austrian school (Burton 1997; see also Beesley and Littlechild 1989; Littlechild 2018), in 1983, presented his report "Regulation of British Telecommunications' Profitability" to the British Secretary of State, which considered the abolition of ex ante regulation as an ultimate goal of the reform. ${ }^{4}$ Unfortunately, real competition never came. The UK government had eventually chosen to restrain the development of competition, and that allowed John Burton to conclude about 15 years later that "the system has not evolved in practice as prescribed by its principal architect into one of the rule of the competitive order. Instead, it has become a system ... [of] ordered competition, ... which has quite different characteristics from that of the competitive order" (Burton 1997).

Again, the roots of this difference are in the understanding by regulators of what competition actually means. The Austrian perspective tells us that competition is a natural process of a free market, but not a product of human design, and, thus, should not be regulated. When regulation maintains competition through ex ante interventions that are aimed in the domain of property rights - such as in the case of mandatory local loop unbundling in telecommunications - we face an example of ordered competition, which is not a result of spontaneous order of free and voluntary interactions of economic actors. It is even might be argued that regulation "touch[es] the central nervous system of the competitive order" (Handler 1973), while "the actual competitive order is the result of individual decisionmaking with regard to prices and quantities ..., ... the result of the choices individuals make in their capacity as entrepreneurs" (Sautet 2010).

\footnotetext{
${ }^{2}$ In his essay "Free' Enterprise and Competitive Order" Hayek notices: “. . . what I mean by "competitive order" is almost the opposite of what is often called "ordered competition." The purpose of a competitive order is to make competition work; that of so-called "ordered competition," almost always to restrict the effectiveness of competition" (Hayek 1949b).

${ }^{3}$ From this point of view, it might be argued that "competition is a disequilibrium phenomenon" (Blaug 2002), while the fundament for perfect competition models is the idea of equilibrium.

${ }^{4}$ See, e.g., analyses of the report in Stern (2003) and Burton (1997).
} 
The distinguishable feature of the telecommunications industry at the moment of the start of the reform in the 1980s-1990s is that market positions and economic power of incumbents by no means were results of market forces. It was regulatory granted market power that could be dismissed at the very beginning at the same time with removal of all barriers for competition in all subfields of the industry in order to move the industry into the direction of the competitive order and to force market mechanisms work. However, the understanding of local loops as an example of a natural monopoly, beliefs that the presence of sunk costs leads to underinvestment in telecommunications infrastructure, and desires to promote efficiency of the field and avoid wasteful duplications shaped the policy of the reform and resulted in the choice of the “ordered competition” regime (see, e.g., Burton 1997; Trubnikov and Trubnikova 2018). As a result, the experience of other western European countries was rather similar to the UK template in the efforts of the governments to eschew the competitive order in the industry. ${ }^{5}$

Meanwhile, there is a widely accepted position that telecommunications policy has not been always and entirely grounded on the perfect competition model. While attempts to base regulation, for example, on the "rate-base rate-of-return" approaches indeed fall into the domain of perfect competition paradigm, there is an opinion that concepts of competition in telecommunications have been, eventually, shifted towards a more dynamic vision, which, in turn, has taken into consideration the contestable market theory and Schumpeterian notion of "creative destruction" (Bauer and Bohlin 2008). However, this new vision has continued to pay significant attention to the problems of sunk costs and economies of scale and to see an important place for the state in the governance of the field. The Russian case exposes how precisely the same theories could be understood in a different way. It shows that contestability can be achieved through a possibility of overlapping of neighboring networks if these local monopolies are sufficiently small. It also demonstrates that the surge of creative destruction could be brought to telecommunications markets by small and medium enterprises which are able to circumvent the high sunk cost problem through implementation of innovative technological solutions. In other words, it shows an alternative for the "ordered competition" choice of the European policy.

From this point of view, it is possible to argue that the unsatisfactory situation with inability of the European telecommunications giants to modernize their networks in the 2000s and the beginning of the $2010 \mathrm{~s}$ is the consequence of the ordered competition choice, market concentration and unwillingness of the governments to disperse the economic power that has not been formed by market forces. Such countries as Germany, France, Belgium, Austria, and the UK are among the outsiders of the fiber network development among the European and OECD countries (FTTH Council Europe 2016; OECD 2015), while European leaders are either in the east of the continent or in Scandinavia. Briglauer and Gugler (2013) notice Sweden, Denmark, and Norway as "Northern European Fiber Nations" and point out that this phenomenon is explained by "a long-lasting history of broadband state aid," and such government participation in the broadband development resembles the strategy in Japan and South Korea that might be considered as "the most mature fiber nations" (Briglauer and Gugler 2013). However, not all territories that have been able to facilitate development of fiber-optic networks relied on

\footnotetext{
${ }^{5}$ According to the literature dedicated to the European experience, the regulatory model of the 1987 Green Paper, which governed the initial stages of the reform, delayed liberalization of public voice telephony until 1998 and stressed the distinction between services and infrastructure. In 1996, "the use of infrastructure for telecommunications services was liberalized to the extent these services themselves were liberalized" (Larouche 2000, $p$. 21), and only in 1998 the full liberalization of telecom infrastructure as well as public voice telephony services finally occurred (see, e.g., Larouche 2000).
} 
governmental aid, and, moreover, the population density, which has a significant impact on the deployment of FTTx infrastructure, of the east of Europe is noticeably lower than the population density of the Asian frontrunners.

Serdarević et al. (2016) expose dissimilarity of telecommunications development in Western European countries and Central and Eastern European $(\mathrm{CEE})^{6}$ countries of the EU and clarify why newcomers of telecommunications markets in CEE countries were able to invest in their own networks without reliance on the incumbents' facilities. The examination of the Bulgarian case by Rood (2010) contributes to the explanation of the superiority of FTTx development of some of the Eastern European countries compared with the more economically developed parts of the EU and points out "esthetical policies" as one of the reasons "why Europe trails other countries in new infrastructure roll out."

The results of these studies of the Eastern European cases correspond with some of the features of the evolution of telecommunications in Russia: the rollout of FTTx networks through the aerial deployment of fiber-optic cables, the underdevelopment of the incumbents' infrastructure at the moment of the start of the reform accompanied by the shortage or even lack of cable TV operators in the markets and the high unsatisfied demand. However, the large distances between industrial centers of the country, the climate, the institutional environment, and an immense level of corruption distinguish the Russian case from its Eastern European counterparts.

The level of development of FTTx networks in Russia and in the aforementioned leading European FTTx countries is represented in Fig. 1. As for the end of September 2015, the highest household "penetration rate"7 of FTTx solutions in Europe was demonstrated by several CEE countries (Lithuania, Latvia, Romania, and Bulgaria), by two of the "Northern European Fiber Nations" (Sweden and Norway), and by Russia. No other European country ${ }^{8}$ was able to show the penetration rate higher than $20 \%$. For comparison, the penetration rate in Germany and Italy just slightly exceeded 2\% threshold in 2015 (FTTH Council Europe 2016).

The Russian figures in the chart are represented by two graphs. One of them is based on the data of FTTH Council Europe, and the second - on the data of Russian Federal State Statistics Service (Rosstat). Despite the results are similar at the end of the analyzed period, the discrepancy of the previous years is noticeable. However, regardless of the chosen source, both pictures of the Russian industry explicitly show that the country has been among the European leaders of the NGA networks at least since the beginning of the 2010s.

\section{The Starting Point of Russian Telecom Reforms}

Deregulation and privatization of telecommunications in the advanced parts of the world coincided with the period of formation of the market economy in the post-Soviet area. However, the process of privatization in Russia, including the privatization of telecommunications, and the process of liberalization of the industry in the developed parts of the world were different, and, thus, the creation of the modern telecommunications markets in Russia

\footnotetext{
${ }^{6}$ Serdarević et al. (2016) define by the term CEE countries Czech Republic, Estonia, Hungary, Latvia, Lithuania, Poland, Slovakia, Slovenia, Bulgaria, and Romania. Four of these countries in 2015 were among the five EU member states whose FTTx penetration exceeded 20\% (FTTH Council Europe 2016).

${ }^{7}$ For the purpose of the research, the term "penetration rate" has the same meaning as in the studies of FTTH Council. (see FTTH Council - Definition of Terms. Available at http://www.ftthcouncil. eu/documents/Publications/FCGA\%20-\%20Definition\%20of\%20Terms\%20-\%20Revisions2016.pdf).

${ }^{8}$ Among economies with at least 200,000 households.
} 


\section{$2011 \square 2012 \square 2013 \square 2014 \square 2015$}

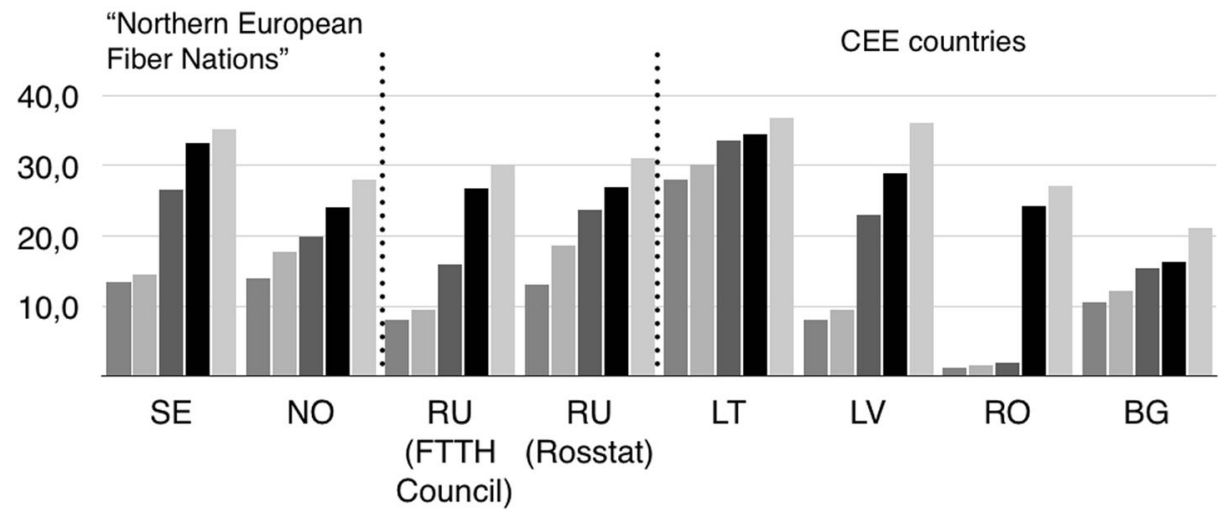

Fig. 1 FTTx penetration rate in the leading European countries (according to FTTH Council Europe and Rosstat)

occurred in a different way. It is very important to notice that "state-led privatization" hardly can be attributed to a free market system, and the Austrian school has paid attention to such peculiarity of this phenomenon (Beaulier 2010). Meanwhile, there are sound reasons to argue that the market played a much more significant role in the privatization process of the telecom industry in Russia than in the advanced European economies. Of course, it is impossible to say that "all privatization efforts ... occur[ed] outside the initiative and central direction of the state," 9 and, moreover, it is clear that the power of the state has been widely used by private entities in their own personal interests, but, nevertheless, the weakness of the state allowed real market participants to take actions outside of the way that was envisaged by state authorities.

During the Soviet period, the communications industry in the country was a single organization, which was governed directly by the specially dedicated Ministry through the regional departments. In the beginning of 1991, the Ministry of Communications, Informatics and Outer Space of the RSFSR ${ }^{10}$ made a decision about the creation of state enterprises based on the regional networks. ${ }^{11}$ It was a significant and doubtlessly positive distinction in the privatization process in Russia, which, perhaps, unintentionally created opportunities for the future formation of the competitive market in the industry. ${ }^{12}$ In other words, the regional telecommunications organizations, which in fact were just departments of the Ministry, were transformed into the regional state enterprises Rossvyazinform (RSI), which, despite the state ownership, now had opportunities for some kinds of autonomous decision-making. More importantly, after this decision, the regional networks stopped to be parts of a single organization, and instead, despite the similar names, they had become

\footnotetext{
${ }^{9}$ See the explanation of "spontaneous privatization" in Hill and Karner (1996).

${ }^{10}$ The process started even before the formal end of the Soviet Union where the Russian Soviet Federative Socialist Republic (RSFSR) was one of the republics.

${ }^{11}$ The decision was expressed in a number of Orders of the Ministry concerning particular regions. E.g., Order of the Ministry of Communications, Informatics and Outer Space of 15.01.91 N 35 was dedicated to the creation of state enterprise Rossvyazinform of Novosibirsk Region. The similar document of the same date with number 31 was about creation of Rossvyazinform of Samara Region and so on.

12 The European way was mainly the opposite. The reform did not envisage divestiture of the state-owned giants. Moreover, some European countries, such as Portugal or Italy, before privatization even decided to integrate the state-owned telecom enterprises that previously operated separately (see, e.g., GSMA 2013; Jordana et al. 2006).
} 
separated from each other. However, they all had a single owner — the state — and they still were under the monitoring of the Ministry. ${ }^{13}$

On 25 July 1992, the Russian Government enacted a Decree about privatization of the communications industry. ${ }^{14}$ This decision supposed that regional RSIs could be privatized on a regional basis, and that after the privatization, the controlling interest of the new companies ${ }^{15}$ should remain in the hands of the state. The next step, according to these plans, was the creation of a new company that would accumulate all state shares of these privatized companies and participate in the control and governance of the new industry. These plans materialized when Svyazinvest JSC was created in September 1995.

Privatization in different regions occurred in different ways. It is outside of the scope of this paper to look at the causes of these distinctions, but it is necessary to highlight one general problem of privatization in Russia, namely, corruption, which played a crucial role in this process. Joseph Stiglitz (2003), for example, even claimed that due to this problem the privatization in Russia should be considered as illegitimate. Jeffrey Sachs, an economist from Columbia University and one of the advisers of the Russian government in the beginning of the 1990s, said in the interview with the PBS about his experience of that time "...Russia experienced a level of corruption really rare in the world. ... [Russian] elite that had grown up in such an amoral, and I think one should say immoral, environment under the Soviet system. Okay, now we're in a private property system, we'll steal it...." ${ }^{16}$ One of the main ideologists of the reform, "the founder of the Russian capitalism," Anatoly Chubais in one of his interviews acknowledged that the question of the reform was not a choice between "honest" and "dishonest" privatization, but between "bandit communism and bandit capitalism" (Ostrovsky 2004).

It is interesting to note that the Austrian school camp has paid attention to the hidden part of the Soviet economy. Anderson and Boettke (1997) in their analysis of "Soviet venality" question the dogma that the Soviet economy was a genuinely centrally planned system. They argue that this economy had a substantial private sector, and this private sector heavily relied on bribery and other forms of corruption, which were "endemic for the system" (Anderson and Boettke 1993). In this analysis, the authors emphasize that "[u]nofficial economic activity was based on evasion of legal entry restriction," and, thereby, they contrast the official part, which did not envisage competition in the economy, and the "market" part, where competition was often an outcome of illegal activities. For example, Anderson and Boettke (1997) notice that "entry into competition with officially sanctioned suppliers was technically prohibited, but could be achieved in practice by "paying-off" the enforces of the restriction." They also distinguish between two types of this "second economy" activity, where the first type relates to "the exploitation of monopoly positions by the officially appointed holders," while in the second case, there are "attempts by outsiders to enter into competition with the established monopolists." Therefore, it might be argued that by the time of the start of the transition towards the market economy, the Russian society had already had a great experience of gaming the system practices and that had been widely exploited during the 1990s and early 2000 s while the power of the elite to enforce the captured rules was comparatively weak.

\footnotetext{
${ }^{13}$ After the collapse of the Soviet Union, the Ministry has changed its name several times, and for some period, it even lost the status of the Ministry. Currently, the name is the Ministry of Digital Development, Communications and Mass Media of the Russian Federation. However, in general terms, regardless of the precise name at a particular period, for the purposes of this article, it might be referred as the Ministry of Communications.

${ }^{14}$ Decree of the Government of the Russian Federation of 25.07.1992 N 526

${ }^{15}$ At that moment not less than $38 \%$.

${ }^{16}$ See interview with Jeffrey Sachs in Commanding Height (Jun. 15, 2000) available at http://www.pbs. org/wgbh/commandingheights/shared/minitext/int_jeffreysachs.html
} 
Corruption, accompanied by weak state institutions, allowed to privatize what could be privatized. In other words, it can be represented by a picture where bureaucrats on various positions in governmental bodies and state enterprises "maneuver[ed] for better rent opportunities" during this period of "experimentation" (Anderson and Boettke 1993). Of course, not all had the same opportunities and not all were nimble enough. The other problem is that big parts of privatized property were under control of the elite of the country, ${ }^{17}$ but to find ways to efficiently use a position of a top manager of new established RSIs for personal interests in the turbulent conditions was really possible. For some, it was possible to grab a part of "conditional" property of RSIs, because some assets were not documented in the proper way due to the mess in the Soviet economy. ${ }^{18}$ For others, it was possible to protect private affiliated companies through formation of favorable contracts with incumbents about interconnection or the use of infrastructure of an RSI due to the weakness of central control from the new controlling authority.

Another possible way to benefit from the heritage of the former Soviet property in the industry was the usage of internal networks of industrial enterprises. During the Soviet period, many factories had their own telecommunications departments and managed to find ways to provide telephone services to other departments and even to the personal needs of their employees. Huge factories, which produced aircrafts, engineering equipment, etc., had their own telephone networks with connection to the public switched telephone network (PSTN). After the privatization in many instances, the telecommunications departments of these organizations became separated companies that already had subscribers and interconnections with the successors of RSIs.

There is also remarkable case of TransTeleCom (TTK), which benefited from the infrastructure of the Soviet railroads. The company, being the subsidiary of the Russian national railway operator (RZD), has had the ability to use the railroad infrastructure in order to develop the national fiber-optic networks connecting the major Russian cities, and eventually become a noticeable player in the wholesale access market.

\section{Evolution of the Order of the Russian Telecommunications Sector}

The chaotic privatization process that tore apart the industry on the regional basis and in many instances within the regions provided the ground for the future competitive landscape. A number of privatized networks of former Soviet industrial enterprises became independent players in this new market. They had their own infrastructure and did not have to rely on the access networks of the former Soviet telecom monopoly. Newborn companies created through the use of positions of senior executives of the RSIs were even able to separate control over core parts of the local telephone networks, and that made such alternative operators independent not only on the issues of infrastructure, but even on the issues of interconnection. The core parts of the local networks in many instances by the end of the 1990s were shared by different

\footnotetext{
${ }^{17}$ E.g., Guriev and Rachinsky (2005) point that some Russian oligarchs just "converted their de facto control [over Soviet state enterprises] into ownership rights."

${ }^{18}$ E.g., in Decision of 24.04.2009 on the case No. A55-17125/2008 of the Arbitration Court of Samara Oblast (VolgaTelecom v. The Federal Service for State Registration of Samara Oblast), we can find that VolgaTelecom OJSC, the successor of the former Soviet monopoly in Volga Federal Region, was very surprised when realized that the part of the regional telecommunications infrastructure had been registered as a property of another company by the Federal Service for State Registration.
} 
companies, and a telecom enterprise seeking interconnection could interconnect its network to PSTN through the alternative operators of the backbone without the necessity to connect the network directly with the former monopoly.

Some available data highlight the scope of pluralization of the industry after the initial stage, which occurred in the 1990s. If we look at the register of telephone numbers distribution of the middle of the 2000s, which to a large extent reflects the historical picture formed in the 1990s, we will find that in some cities such as Saint-Petersburg, Kazan, Samara, and Ekaterinburg there were dozens of telephone companies, and their number in Moscow exceeded one hundred. According to available data, at the end of the 1990s, there were 92 incumbents in the local markets of telephone services and about 2700 independent telephone operators. ${ }^{19}$ One of the directives of the national antitrust authority, for example, placed in the register of natural monopolies, in January 2001, 55 alternative telephone operators just of one Samara region (34 from Samara, the city with population less than 1.2 million inhabitants). ${ }^{20}$ Among these companies, there are many industrial enterprises from various spheres and independent business endeavors that were previously telecommunications departments of these enterprises, several comparatively big operators affiliated with former officials of the Soviet telephone monopoly, public transport enterprises and its former departments, agricultural enterprises, companies affiliated with the energy industry, an enterprise belonged to the Ministry of Defense, several research institutions and even a university. Many of these companies provided services in small areas of the city and had only hundreds of subscribers.

The justification of the placement of these companies in the register of natural monopolies was grounded on the widespread assumption that telephone networks even after its divestiture continue to exercise monopoly power in a local form. In other words, according to this viewpoint, pluralization just separates one big monopoly to a number of small monopolies. However, this position can be challenged by the main assumptions of the contestable market theory, which claims that even those markets that have a monopolistic or oligopolistic structure might provide the same outcome as competitive markets (Baumol et al. 1982). Spulber and Yoo (2013), for example, notice that "[t]echnological change ... has made telecommunications markets contestable by reducing the sunk costs associated with market entry." Pluralization of the field makes the costs of entering into neighboring territories even lower, and, thereby, creates an environment where overlapping of neighboring networks is feasible. If the network structure is represented by a number of independent networks, these local monopolies can be destroyed by the real market process. The Russian case explicitly shows this peculiarity, which eventually resulted in overlapping of networks and provision of fully competing services through independent telecommunications infrastructures presented in the same districts and same buildings.

A decade and a half after the start of the reforms, while some wondered about even the feasibility of competition in telecommunications (Ofcom 2004), the telecommunications

\footnotetext{
${ }^{19}$ See "Conception of development of the market of telecommunications services of the Russian Federation" (approved by the Government of the RF on 21.12.2000). The document is available on the website of the Federal State Enterprise STC “Infromregister” http://www.inforeg.ru/library/item/135

${ }^{20}$ See Prikaz Ministerstva Rossiyskoy Federazii po Antimonopol'noy Politike i Podderzhke Predprinimatel'stva ot 15 yanvarya $2001 \mathrm{~g}$. N 8 [Order of the Ministry of Antimonopoly Policy and Support of Business Undertakings of the Russian Federation of 15.01.2001 N 8] (Russ.). After the inclusion in the register of "natural monopolies" a company had to charge, usually, the same rates as the incumbent and could not implement different price policies, could not sell bundled services, and could not use unapproved methods of price formation.
} 
industry in some Russian regions evidenced benefits of the competitive marketplace. It was a common situation in many Russian cities when at the end of the 2000s two to three broadband services providers had their own infrastructure in the same buildings in addition to the incumbent's infrastructure.

Moreover, by the time of transition towards the broadband paradigm, not only the local markets had a competitive form. The same can be said also about the wholesale access markets. As it was mentioned earlier, TTK with its advantage of access to the railroad infrastructure had been able to construct a countrywide network based on fiber-optic technological solutions. There were companies who got access to electric power transmission systems in order to use it for placement of their fiber-optic lines. There were also mobile networks that connected their elements throughout different regions and that allowed them to participate in the wholesale access markets. There were as well spin-offs from the former monopoly whose appearance had the very same nature as the appearance of many local companies, where the management had found ways to start their own business undertakings using the assets of the controlled enterprises. ${ }^{21}$

Nevertheless, due to the prevalence of the private interests in the regulatory policy, the industry was unable to avoid dependence on the incumbents and the state. If to draw a timeline of the industry's evolution in the country, it would be reasonable to link the timeline with the main points of organizational development of the former monopoly. This process started with the separation on the regional basis of the original monopoly and the chaotic market activity of the regional business not heavily constrained by regulation, and ended in 2012 with the reincarnation of the former giant and the consolidation of the main industry's assets.

The evolution of the industry within this more than 20-year period has demonstrated different levels of concentration of the field and eventually resulted in the reincarnation of the former Soviet monopoly. The analysis of this evolution allows to argue that there are no robust evidence that the process of the industry concentration is a market-driven process. The Russian case exposes that the concentration is an outcome of vested private interests in regulatory policy, while the decentralized industrial structure and independent entrepreneurial activity are the necessary prerequisites for the efficient work of the market process. The Russian telecommunications case provides empirical support for the claims about the superiority of the competitive order regime over the ordered competition alternative, and shows that the satisfaction of actual social needs in this sector does not require government interventions in market mechanisms.

\subsection{Post-privatization Period of the 1990s}

As was described in the previous section, the initial phase of this timeline was privatization of the regional assets of the former monopoly with preservation in the hands of the state the controlling stakes of the new enterprises. The initial privatization in Russia in the beginning of the 1990s took a form of voucher privatization, where active participation was taken by senior executives of the companies and regional business and criminal groups. Some researchers, who studied privatization of telecom in Russia, pointed out that for many privatized companies it was unclear who had become their real new owners and that in some cases it took several years before the first shareholders meetings took place (Bychkova 2002). During this period,

\footnotetext{
${ }^{21}$ This interrelations of private business interests and professional duties of top executives is still widely observed in the Russian economy. According to the survey published by RosBusinessConsulting in 2016, $27 \%$ of Russian top managers have their own business undertakings and this personal business activity of about half of them closely relates to the main activity of their employers ( $R B C$, Feb. 4, 2016).
} 
not only did the state not have robust control over the industry development or the activity of independent enterprises that already appeared in the field, but it even did not have control over the former monopoly where it still remained the main shareholder.

This autonomy not only provided opportunity to increase the personal wealth through the use of the former Soviet property but also gave chances to make autonomous decisions about equipment procurements and creating partner relationships with foreign investors (Bychkova 2002). Moreover, the pluralistic landscape of the telecom industry fostered pluralism of technological solutions and competitiveness of the newly formed telecom equipment marketplace. Many manufacturers were ready to supply their solutions with lucrative payment terms and considered the first steps in the Russian territory as strategic for their future market positions. As a result, just over few years of the openness of the industry, from 1990 to 1995, the number of households with access to PSTN had increased by about $28 \%,{ }^{22}$ despite the catastrophe in the country's econo$\mathrm{my}^{23}$, hyperinflation ${ }^{24}$, and unsteadiness of the new political system.

The second phase of the timeline can be defined as an attempt of the state to take back control through the formation of organizational accountability of the regional incumbents and regulation. In 1995, the creation of state-owned Svyazinvest JSC, which accumulated the controlling shares of the privatized regional assets of the former monopoly, ${ }^{25}$ was accompanied by the enactment of the Federal Law "About Communications" 26 . One year later, in October 1996, the Government introduced the "Rules of interconnection" "27. However, these first attempts hardly might be considered as successful form the point of view of the regulatory functions. In many instances, the appearance of Svyazinvest was merely unnoticeable by the management of the regional incumbents because the new powerful state holding initially did not represent serious threats to the autonomy of the regional business (Bychkova 2002). The same was the case of the new legal statutes - they contained many fuzzy norms and did not entirely reflect the new reality of the industry.

The absence of the control facilitated incorporation into the activity of the regional incumbents the personal interests of their managers and, again, played in favor of pluralization of the field. New entrants were able to get access to the incumbents' infrastructure or interconnection points, solving these issues at local or regional levels, and that fostered attraction of investment to the industry from different groups of investors, among whom the small and medium regional business had a noticeable role. One of the possible methods to get access to the resources of an incumbent was creation of joint ventures, and this method was lucrative for mobile business start-ups. By the end of the 1990s, markets of mobile telephony of a number of Russian regions already had a competitive landscape, and many of the mobile operators were independent from incumbents and from powerful national players. There were even cases where powerful Moscow companies cooperated with local regional business in order to enter the region, and these ventures also had a significant degree of autonomy. ${ }^{28}$

\footnotetext{
$\overline{22}$ From 14.6 M in 1990 to $18.7 \mathrm{M}$ in 1995 (according to Rosstat).

${ }^{23}$ GDP declined from $\$ 517.963$ billion in 1991 to $\$ 395.531$ billion in 1995 (according to the World Bank).

${ }^{24}$ Consumer Price Index in 1992 was $2608.8 \%$, in $1993-939.9 \%$, and in $1994-315.1 \%$ (according to Rosstat).

${ }^{25}$ There were several exceptions when the regional companies retained their independence from Svyazinvest.

${ }^{26}$ Federal Law "About Communications" of 16.02.1995 N 15-FZ

${ }^{27}$ Decree of the Government of the Russian Federation of 19.10.1996 N 1254

${ }^{28}$ E.g., Beeline-Samara OJSC was a joint venture of VimpelCom and a regional business of Samara; Ekaterinburg Cellular Communications worked under the VimpelCom's trademark "Beeline" and after the independent entrance of VimpelCom in the market of the region decided to continue the autonomous activity under the new brand MOTIV.
} 
Thereby, the landscape of the wireless sphere in the 1990s was also to a great extent an outcome of a spontaneous process. Initially, the spectrum was not assigned on a countrywide basis for a few operators. On the contrary, there were dozens of mobile companies, many of which operated only in particular regions (see, e.g., RosBusinessConsulting 2002). The distribution of the radio spectrum has never been transparent in the country, and it provided opportunities in the early days of the market formation for some regional players to solve the necessary issues related to the frequencies allocation for the development of their networks. Meanwhile, the competition for "regulatory goods" on the mobile market was not less important than the competition for subscribers, and those who lost the battle for regulation, eventually, were forced to leave the market of mobile services (see, e.g., Filonov 2014). The analytical report of informational agency RosBusinessConsulting shows that in 2001 the mobile telephone market of the country was shared between six big players, many regional operators and regional successors of the former soviet monopoly (RosBusinessConsulting 2002). However, already by the middle of the 2000 s, their number had dramatically decreased due to the high activity in the sphere of mergers and acquisitions, and assignment of available by that moment parts of the spectrum to the national giants affiliated with the Russian oligarchies.

The results of these "wild west" processes of the 1990s were expressed in the beginning of the $2000 \mathrm{~s}$ in competitive markets of the fixed telephony of the most economically advanced Russian regions, and in four to five companies active in the mobile markets of these regions, where the national leaders competed with local rivals. However, this period can be also characterized as a period of the beginning of concentration of private interests in the industry and the increasing government role in the process.

In 1997, 25\% plus one share of Svyazinvest was sold by the Russian government to Mustcom Ltd., the investment group where one of the key figures was George Soros' Quantum Fund. The developing new Russian oligarchy also actively participated in this process, as well as in the formation of the main industrial groups in the mobile and fixed markets. It was also a period of entrance in the Russian market of foreign companies, which played both positive and negative role in the development of competition. Such companies as Telia, Sonera, Deutsche Telekom, Telenor have noticeably contributed by their participation in the mobile Russian business into eventual oligopolization of the field. ${ }^{29}$ Others invested in the development of regional networks and, thereby, promoted pluralization of the landscape (e.g., Global $\mathrm{One}^{30}$, Combellga ${ }^{31}$ ). One of the most remarkable alternative players in the fixed industry became Golden Telecom, the company that, as well as Svyazinvest, was affiliated with George Soros through the group of other companies-Sovintel and Global TeleSystems (GTS) ${ }^{32}$.

\footnotetext{
${ }^{29}$ Telia and Sonera participated in the creation of Megafon (see http://www.teliacompanyhistory. com/sources/svenolof-karlssons-the-pioneers/the-pioneers-page-85/). Deutsche Telekom played an important role in the foundation of MTS (see http:/www.company.mts.ru/comp/company/history/). Telenor in December 1998 formed strategic Alliance with VimpelCom and acquired a share in the Russian company (see https:/www. vimpelcom.com/Media-center/Press-releases/1998/VimpelCom-and-Telenor-enter-into-strategic-alliance/).

${ }^{30}$ International consortium of Deutsche Telekom, France Telecom, and Sprint.

31 Joint venture with participation of Alcatel Bell and Belgacom.

${ }^{32}$ About the affiliation of GTS and the Russian companies see, e.g., Kommersant Newspaper, Oct. 6, 1999, N. 182. Available online at https://www.kommersant.ru/doc/226874 (in Russian)
} 


\subsection{New Industrial Policy and the Broadband Revolution of the 2000s}

The appearance of this concentrated interests led to alteration of the structure of Svyazinvest and its regional subsidiaries and to the formation of the new industrial policy. This may be considered as the next stage of the timeline. At the end of 2002, the regional assets of Svyazinvest merged into seven Interregional Communications Companies (ICC), and that was accompanied by the introduction of new regulatory frameworks. Meanwhile, it is possible to argue that these frameworks were mainly aimed to eliminate the regulatory gap that allowed independent market participants to act in the issues of interconnection with the giants as peers.

The Federal Law "About Communications," which was enacted by the Russian Parliament in 2003, separated the telecommunications companies into two groups: "interconnecting companies," which provide interconnection services, and "interconnected companies," which receive these services. The new frameworks introduced state regulation of prices for interconnection ${ }^{33}$ and rules of "interconnection and interaction of telecommunications networks" 34 , and, thereby, not only brought state regulation of the procedure of interconnection, but also established rules on how companies should make interpayments for the interconnection services, and how they must organize the transmission of telecom traffic and deploy their networks. The framework prohibited interconnection between some networks, and force independent operators in many instances to organize connections through the networks of subsidiaries of Svyazinvest. ${ }^{35}$

Moreover, the actual regulation of interconnection prices in many cases could be properly treated as a price squeeze, because the cheapest termination rates of incumbents had been established by the state authorities on about the same level as the price for a minute to an enduser. $^{36}$ The alternative operator had no opportunities to charge its subscribers more due to the competition, but, at the same time, was forced to pay often more for their calls than received from them. Even in the case of symmetric distribution of telephone calls between the networks of an alternative operator and an incumbent, the economy of small business in this field was becoming quite problematic, because, depending on the network structure and the placement of the interconnection points in this structure, the skewness of the interpayments towards the big company could exceed the total incomes of the small one. ${ }^{37}$

These attempts to take control over the independent movement were supported by the rules that determined the procedure of commissioning of networks and all communication facilities

\footnotetext{
33 Art. 20. Federal Law “About Communications” of 07.07.2003 N 126-FZ.

${ }^{34}$ Decree of the Government of the Russian Federation of 28.03.2005 N 161

${ }^{35}$ Order of the Ministry of Communications of Russia of 08.08.2005 N 97, and Order of the Ministry of Communications of Russia of 08.08.2005 N 98.

${ }^{36}$ E.g, according to Order of the Federal Tariff Service of 23.11.2007 N 294 in Saratov region the maximum rate for local telephone services was established on the level 0,22 rub. per minute (including VAT). The cheapest price of VolgaTelecom, the subsidiary of OJSC Svyazinvest in the Volga Federal District, for interconnection services in the same region was established by Roskomnadzor (Order of the Federal Service of Supervision in the Sphere of Communications of 19.06.2006 N 51) on the level 0,2242 rub per minute (including VAT).

37 The rates depend on a number of telephone exchanges used in the termination of a call, and since big networks have more complicated topology, the average termination rates of incumbents are generally higher than the average rates of small telecommunications enterprises. The most expensive rates have been "termination on a network of another operator with two or more transit nodes," where the rates in some regions are more than several times higher than the prices for end-users. For instance, the described above example of Saratov region shows that interconnection rates could reach 0.59 rub per minute (including VAT), i.e., about 2.7 times higher than the rate for end-users. For the analysis of this economy, see Trubnikov and Trubnikova (2010, pp. 157-187).
} 
that could be used in telecommunications services, ${ }^{38}$ and these rules imposed new regulatory burdens on alternative telecommunications companies. This regulatory approach not only allowed to control the entry of new players and development of their networks and services, but also helped to force alternative operators to comply with the rules of interconnection that were highly beneficial for the incumbents.

The efforts to restore control over the industry and empowering of the most influential players of the field by the middle of the 2000s has started to bear its fruits. By that time, the ICCs finalized their organization and moved the entire managerial functions from the regions to the macro-regional centers. The entire mobile market of the country was on its way towards the national arena for just several players, the powerful Moscow companies with participation of foreign capital such as Golden Telecom or Comstar-OTS were acquiring regional telecom businesses throughout the country. The formation of interconnection rules and rules concerning the structure of the networks forced many players to quit the marketplace through the selling of their enterprises. Nevertheless, the processes of the second part of 2000s showed that the pluralistic landscape of the industry, which still remained by that period, provided fertile soil for the creative destruction process, and that opened opportunities for new ventures that brought innovations in the field.

The start of the Internet expansion in Russian regions happened later than in the advanced economies. In the beginning of the 2000s, just a tiny part of households had personal computers, and the demand for Internet access was mainly formed by commercial organizations. Because the industry in many of the regions was represented by a number of telecommunications companies that possessed their own infrastructure and was independent in its development from the former monopoly, it gave birth to appearance of independent Internet Service Providers (ISP) that did not have to rely on the kindness of the official incumbents' policy in order to get access to the local loops - they could obtain this access either to the wires of independent players, or even to the wires of incumbents through their personal relationships with local management of the former monopoly. However, by the middle of the 2000s, the later opportunity had about almost disappeared.

The Russian regulation has never tried to solve the problem of local loop unbundling. This unbundling was to a large extent a natural outcome of market forces. Many local telephone companies in the beginning of the 2000s did not consider Internet business as a field for their development. For them, the appearance on their local loops of external ISPs was merely an opportunity for additional revenues for their telephone undertakings. Possibly, the most prominent example is the cooperation between MGTS and MTU-Intel, which allowed the latter to become the leader in the broadband market of Moscow by 2006 (Gabitov 2006). ${ }^{39}$ This situation played in favor of formation of a market of Internet access separated from the telephone business, and a competitive landscape of this field had been formed. ${ }^{40}$

Strengthening of regulation, consolidation of the telephone assets, elimination of the autonomy of the major regional players and increasing activity on the Internet market mainly through promotion of ADSL technology of the federal companies raised crucial issues for local

\footnotetext{
${ }^{38}$ Order of the Ministry of Communications of the RF of 09.09.2002 N 113. The document was substituted by the new rules only on 01.01.2015 (Order of the Ministry of Communications of the RF of 26.08.2014 N 258). ${ }^{39}$ See the history of MGTS on http://mgts.ru/company/foundation/ where the collaboration with MTU-Intel is advertised in 2004.

${ }^{40}$ It is very important to notice that situation was different in different territories, and competitive Internet access markets were mainly formed in those regions where competitive telephone markets were an outcome of the "wild" 1990s.
} 
ISPs about their future positions in the market. The most apparent solution was the use of alternative technologies of Internet access that would be better suitable for the growing demand. The solution had been found in technologies of wireless broadband access and FTTx, and the two following subsections are dedicated to the analysis of development of these two alternatives for copper networks, which eventually expressed in the one of the highest in the European continent levels of development of NGA networks.

\subsubsection{Wireless Broadband Access}

In general, the start of the development of wireless access networks in Russia was mainly warranted by the insufficient copper infrastructure in low population density areas, which in many instances made wireless access the only possible solution for the service provision. Such exclusivity allowed to charge higher prices than the prices of wired services, what at the same time was backed by the higher costs of the services provision, and, as a result, the service was a very niche category that was interesting neither for incumbents, nor for the major federal players.

The companies that developed such networks used a number of incompatible technologies that worked in different radio bands. Since these markets were not interesting for major players, and since they also did not consider these radio bands for their future developments, obtaining such radio frequencies proved feasible for alternatives companies. There was a number of such networks in different regions of the Russian Federation that were mainly independent from each other and could be represented by small often almost invisible dots on the map of the country.

In 2005, the situation has changed dramatically. The appearance of WiMax had allowed to look at the broadband wireless market not only as a possible alternative for traditional fixed services but also as at the field that would change the nature of the entire wireless industry (Trubnikov 2017). A number of Russian entrepreneurs embraced the vision of the future of telecommunications industry promoted at that time by Intel Corporation, and launched the projects of WiMax networks with plans to become the federal providers with a coverage area of the scope of the country. By 2008, fixed WiMax networks had been deployed in a number of Russian regions by Enforta and MetroMax. There was also the entrance to the wireless business of Virgin Group that had a goal to capture $10 \%$ of all broadband access market of the country within 5 years (CNews.ru, May 15, 2008). Several other alternative companies announced their plans to invest in WiMax development and to enter the battle for the wireless market of Russia, and many of them began the realization of their intentions (Summa-Telecom, FreshTel, Synterra, Corbina Telecom, Mediaseti, ACBT, and so on).

The WiMax movement in Russia had a positive impact on the development of entire broadband networks in the country. The private investment in the broadband solutions contributed to the backbone development, which, in turn, became essential elements of the growing FTTx networks. It gave the industry understanding how to solve existing problems of infrastructure shortage, and that was expressed in the rapid development of local broadband networks that used various kinds of cheap wireless equipment that allowed to provide access to remote territories, and that even was used to connect separated parts of FTTB networks.

\subsubsection{FTTB}

The second part of the first decade in the 2000s in the Russian telecommunications was characterized by the exponential growth of broadband networks that were based on the fiber 
optic to the buildings approach (FTTB). The frontrunners of the development of FTTB networks in Russia were not the established federal companies. On the contrary, their networks represented the classical examples where the "replacement effect" stifled the development of the more advanced technology. At the same time, the alternative ISPs, which did not have their own copper infrastructure and that understood that for their future business positions they have to enter the infrastructure market, were the main players in the beginning of the process who moved the fiber closer to the subscribers.

Moreover, the FTTB solutions have changed the economy of telecommunications dramatically. The prevailing view that the industry's development requires high level of investment that usually refers as high level of sunk (fixed) costs had become irrelevant to the area. The FTTB networks demonstrated the totally opposite paradigm: the cable and the work with the cable are comparatively cheap, ${ }^{41}$ the growing market of computer networking equipment supplied to the alternative players switches and routers that provided inexpensive solutions for the access network, ${ }^{42}$ and the formed market of "used Cisco"43 allowed to small independent enterprises to find affordable equipment for the core parts of their networks.

As a result, the absence of regulation of bottlenecks was not a problem for the alternative companies, because they did not need this access at all. They could develop their own infrastructure, but the problem was where to place this infrastructure. If the FTTB networks were not expensive endeavors, the technology was not able to change the high costs of construction of underground ducts. Since the significant parts of the existed underground ducts were controlled by the former monopoly, aerial wiring appeared as an obvious solution for the networks rollout.

Therefore, many companies that wanted to develop their own cable infrastructure understood that they had to find ways to make contracts either with a company that is in charge for public lighting, tram-trolleybus authorities or with those who maintained buildings. An interesting fact is that there were some legal restriction to hang the communications cables that contained conducting elements on the lampposts, while for dielectric types of fiber-optic cable such restrictions did not exist. This aspect spurred the development of fiber-optic networks in the big cities, which had by the middle of 2000s competitive telecommunications marketplaces, and encouraged the implementation of FTTx solutions. The remarkable picture of the Moscow market shows that $24 \%$ of the market share in 2006 was under the control of companies that had less than 2000 subscribers each. ${ }^{44}$ Taking into account that the broadband penetration estimated at the level of $21 \%$ of households (Gabitov 2006), it is possible to infer that there were hundreds of the small ISPs in the broadband market of Moscow at that period. Moreover, despite the fact that the major players of the market used ADSL technology (Gabitov 2006; Potresov 2006), the share of subscribers connected through FTTB networks in Moscow already achieved at that time 57\% (Potresov 2006).

\footnotetext{
${ }^{41}$ However, this note is not applicable to the construction of the ducts or to the placement of the cable in the ground.

${ }^{42}$ Some examples of prices of the computer networking equipment, as well as of fiber optic cables in the Russian market might be found at https://shop.nag.ru/catalog.

${ }^{43}$ See, e.g., http://www.usedcisco.ru

44 The Moscow market of the broadband access in 2006 was presented by the following figures: $21 \%$ of households had broadband access to the network, $37 \%$ of them had been connected through ADSL by MTUIntel (nowadays, the business is a part of MTS), $17 \%$ by the big three Moscow telecommunications companies of that time (Akado, Corbina-Telecom, OPJS Central Telegraph), $9 \%$ by other "big" companies (that had more than 10,000 subscribers each), $13 \%$ by "medium" providers (that had more than 2000 , but less than 10,000 subscribers each), and rest $24 \%$ by small operators (that had less than 2000 subscribers each) (Gabitov 2006).
} 
The interesting competitive landscapes had been also formed in the regional markets where incumbents and powerful federal companies faced severe competition from the independent movement. For example, in Chelyabinsk, which has a population of about 1.13 million inhabitants, in 2008, 58.6\% of the broadband subscribers had the access through FTTB solutions (Kusch 2008). The leader of the market with about $40 \%$ of the market share was local company Intersvyaz. The incumbent, one of the ICCs of Svyazinvest, Uralsvyazinform was on the second position with about $33.9 \%$. The market share of the only federal player ERTelecom was less than $10 \%$, and the rest was shared by many small and medium enterprises, whose total number exceeded two hundred. There were also remarkable examples in Ekaterinburg, Kazan, Novosibirsk, Omsk, Samara, etc.

Even in those cities, where rivalry in the market had not been formed by 2006, new entrants still were able to use the same "aerial wiring" business model. ER-Telecom, which started its federal expansion from Perm Oblast in 2005-2006 and has become one of the country leaders in the fixed broadband access market and in the market of cable TV, mainly used this approach in the development of their networks. By 2015, the company had entered the markets of 22 Russian regions, and it did not depend on the infrastructure of the major players in this process.

The appearance of ER-Telecom, as well as the activity of a great number of independent ISPs that rolled out their own FTTB infrastructure, forced the established players to change their methods of service provision and substitute ADSL access networks by FTTB solutions. ${ }^{45}$ The example of ER-Telecom encouraged MTS to follow the same approach and construct their own FTTB networks, developing the acquired venture of Comstar-OTS. For example, in Rostov-on-Don, the company constructed the FTTB network in the same districts of the city where other companies such as the incumbent RTK and the noticeable player SPARK, ${ }^{46}$ as well as several small local operators, already were doing their business. Similar pictures were observed in Volgograd, Saratov, Ulyanovsk, Krasnodar, Samara, and many other regions of the country. Moreover, this picture is not only the feature of the big cities. It is possible to meet a number of small enterprises that were active in small towns with the presence in the market of several powerful companies and that even managed to attract investments in the development of their FTTB infrastructure. The results of this activity have been expressed in the existence of parallel infrastructures, when several telecom enterprises were presented at the same time in the same buildings and competed by their own wires.

The FTTB approach for network constructing has become so popular in Russia that even providers of cable TV services have implemented it for Internet access provision, what again differs the Russian case significantly from many of its western European counterparts. According to J'son and Partners Consulting, in 2012, only 4\% of subscribers of the broadband market in Russia had access through the DOCSIS technology (IKS Media, Feb. 8, 2013). The main advantages of bringing the fiber closer to subscribers are the relatively low costs and scaleability of these solutions. Many cable TV providers in Russia, which due to historical circumstances at the end of the 2000s to the beginning of the 2010s used DOCSIS, had been forced to change their implemented solutions to FTTB (see, e.g., CNews.ru, Apr. 6, 2010; RusCable.Ru, May 31, 2011). However, there were also the opposite decisions: when one of the biggest DOCSIS players in the Russian market Akado Telecom, in 2014, faced a dilemma

\footnotetext{
${ }^{45}$ According to available data, in 2012 , about $31 \%$ of the broadband subscribers of Rostelecom (RTK) were already served though FTTx infrastructure. By 2017, the share of FTTx subscribers in the RTK broadband business was already $63 \%$ (CNews.ru, May 17, 2018).

46 The TM of CJSC "Electro-Com," which was acquired by TTK in 2012.
} 
to upgrade its DOCSIS 3.0. network to DOCSIS 3.1. or to substitute it with a new FTTB infrastructure (ComNews, May 27, 2014), the company had chosen the former option; and later, it sold its assets in Saint-Petersburg and Ekaterinburg to the more successful FTTB rival, ER-Telecom (ComNews, Nov. 17, 2017).

\subsection{Reincarnation of the Soviet Monopoly}

The growing power of the state and prevalence of private interests in regulation of economic activity in the Russian Federation has moved all the industries of the country towards concentration. About all spheres of economic life have been becoming more and more concentrated, and the control over regional economic resources have been transforming to the hands of powerful business groups from Moscow. Even Russian officials have admitted that the "high level of monopolization" is a "scourge" of the Russian economy. ${ }^{47}$ It has expressed in the tremendous level of inequality in the country, ${ }^{48}$ the current economic situation and the capital outflow that dramatically increased after $2007,{ }^{49}$ and it has also coincided with the growing level of perception of "state capture" (World Bank 2013), growth of corruption ${ }^{50}$, declining democratic institutions, and almost absence of the rule of law ${ }^{51}$.

Telecommunications have not been an exception from this general pattern of concentration. The eventual monopolization of the industry was programmed in the beginning of the reform, and the next step of the development of Svyazinvest was a merger of all of its separated assets into a single organization. In 2011, all Interregional Communications Companies (ICC) had been connected to Rostelecom, another subsidiary of Svyazinvest, which during the privatization process was separated into a state-owned operator of intercity and international telephony. In 2012, Svyazinvest merged with its subsidiary Rostelecom, forming the single organizational structure that had integrated the telecommunications assets of the country where the state had had the controlling interest after the privatization of the 1990s. Since that moment, the new questions about privatization of the state shares of Rostelecom have been raised a number of times, but there are no reasons to assume that this new stage of privatization might be in any sense a pro-market or pro-competitive endeavor.

The concentration of the field has also expressed in the slowdown of the industry development. According to the official data of Russian statistics, the exponential growth of broadband subscribers has turned to just 15\% over the period 2013-2016, where in 2016 the growth was only $2.6 \%$. Moreover, over this three-year period, some of the regions showed decline in the number of the fixed broadband subscribers (Moscow, Volgograd Oblast, Udmurt Republic, Orenburg Oblast, Krasnoyarsk Krai, Omsk Oblast, Kamchatka Krai, and Chukotka

\footnotetext{
${ }^{47}$ The speech of the first vice-chairman of the Central Bank D.Tulin. See Gazeta.Ru, Jan. 19, 2016 (Available at http://www.gazeta.ru/business/news/2016/01/19/n_8138117.shtml)

${ }^{48}$ According to Credit Suisse Research, in 2014, Russia had one of the highest levels of inequality among the analyzed countries, and this figure had significantly increased over the preceding seven years. The report claims that " $[\mathrm{t}]$ he majority of countries, including many big players on the international scene - Brazil, India, Indonesia, Russia, South Africa and Turkey - qualify as "very high inequality"..., inequality in Russia is so far above the others that it deserves to be placed in a separate category" (Credit Suisse 2014).

${ }^{49}$ The information is available on the official web-site of the Central Bank of Russia at www.cbr.ru/statistics/ credit_statistics/bop/outflow.xlsx

${ }^{50}$ See, e.g., the Corruption Perception Index published by Transparency International. Available at https://www. transparency.org/research/cpi/overview

${ }^{51}$ The weakness or even absence of the rule of law in Russia have been noticed by many observers (see, e.g., Kramer 2011).
} 
Autonomous Okrug), and the growth in many others did not exceed 5\% (Kaliningrad Oblast, Leningrad Oblast, Murmansk Oblast, Novgorod Oblast, Republic of Ingushetia, Republic of Tatarstan, Samara Oblast). Of course, in some of these cases, such as Moscow, Samara, or Kazan, it would be possible to suppose that the industry due to the previous competitive form has been already able to achieve the penetration level that close to the actual demand, but such explanation cannot be applicable to all territories.

Nevertheless, the competitive period has allowed the industry to be among the European leaders of the telecommunications development. Even after the consolidation of the main assets, broadband markets of many of the Russian regions have been able to preserve a competitive landscape. The growth of FTTx penetration has been to a large extent a result of rivalry in this sphere, which, despite the economic stagnation, forces the market participants to increase the quality of the services with preservation of the affordability of the prices. ${ }^{52}$ There is still competition between fixed networks and mobile networks that also affects the rates and to some extent explains the decline of the number of the fixed broadband subscribers in some of the territories.

One of the most distinctive outcomes of the competitive history of Russian telecommunications is that the successor of the Soviet monopoly has not been able to obtain the unconditional dominance in the broadband access markets. Rostelecom possesses the greatest part of the underground cable infrastructure throughout the country (with minor exceptions), including territories where competitive markets have not been formed. The company receives subsidization from the Universal Fund, which redistribute $1.2 \%$ of all revenues from telecommunications services into the business of the incumbent, ${ }^{53}$ and from different state efforts "aimed" at the solution of the "digital divide" problem. Nevertheless, despite all of these aspects and despite the absence of any pro-competitive industrial policy, the market share of Rostelecom in 2013 was only 34.7\% (J'son \& Partners Consulting 2015). At the same time, the alternative regional companies had in 2013 about the same share of the market- $34.3 \%$ (J'son \& Partners Consulting 2015). Three years later, the picture has changed noticeably: Rostelecom-37.7\% and the alternative regional companies - $29.9 \%$ (J'son \& Partners Consulting 2017). Many of the regional companies over the period have been acquired by the major players of the market (J'son \& Partners Consulting 2017), and the trend towards oligopoly of the broadband area is becoming more and more clear.

With the reincarnation of the former Soviet monopoly, the period of the competitive market in telecommunications has come to its final stage. The control over the main resources of the industry have been concentrated within the several powerful groups, and the current existence of the competitive field in the broadband sector is rather a matter of time.

\footnotetext{
52 The cheapest offers of ER-Telecom in May 2017 already started with the speed $40 \mathrm{Mbps}$ and with the price around 400 Rub. (less than 6.5 Euro according to the exchange rate of the end of May 2017). For more detailed information see rates of ER-Telecom on their web-site domru.ru. For comparison of Russian prices for telecommunications services and rates in other countries, see, e.g., results of the studies of TMT Consulting presented by RIA Novosti on Dec. 26, 2016 (Available at https://ria.ru/economy/20161226/1484662033.html) (in Russian).

${ }^{53}$ In 2014, the Government decided that there should be the only one company of the Universal Service and this company is the reunified successor of the former Soviet monopoly Rostelecom (Decision of the Government of the Russian Federation of 26.03.2014 N 437-p). According to the report of the Ministry of Communications (the information is available on the official web-site of the Ministry http://www.minsvyaz.ru/ru/activity/directions/193 ), the annual payment of operators to the "Fund of the Universal Service" is about 15 billions rubles (about \$245 millions according to the average exchange rate of 2015).
} 


\section{Summary and Conclusions}

The Russian telecommunications industry not only poses quandaries for the mainstream theories, as noticed by Stiglitz (1999), it also provides a reasonable ground for reconsideration of the validity of the mainstream assumptions. The case explicitly shows that innovations in the industry do not require a high level of concentration, that all layers of the industry may have a competitive form, and that rivalry is able to flourish in the area even without regulatory efforts to promote competition. The important prerequisite for the efficient work of market forces is the absence of the control over the key resources of the field. When the market environment allows newcomers to develop their networks independently from incumbents, they have opportunities to leapfrog the established players, and, these conditions, in turn, force the incumbents to innovate and to modernize their infrastructure.

Meanwhile, the common pattern of the "deregulatory" movement of the 1990s in different places of the world did not assume formation of the competitive order in the industry and eventually chose the "ordered competition" regime (see, e.g., Burton 1997; Trubnikov and Trubnikova 2018). In Europe, for example, there was not only a lack of placement of all services in the competitive environment at the same time, but even competition in the area of telecommunications infrastructure was not allowed in the beginning of the process of “deregulation" (see, e.g., Larouche 2000).

The distinctive and doubtlessly positive feature of the privatization of the Soviet telecom monopoly in Russia was a separation of the company into state enterprises on regional basis before the start of this process. The personal interests of the managers of these enterprises as well as privatization of the telecom departments of Soviet industrial organizations to some extent facilitated the spontaneous way of privatization and development of the industry, and eventually resulted in the appearance of competitive environment in the telecommunications markets of many Russian regions. As it follows from the analysis, in the early years of the post-communist industry development in Russia, some kinds of activities in the shadow part of the economy contributed to this pluralization. It is interesting to notice that this phenomenon conforms to the view, according to which, when corruption allows "to get around ... bad laws," it may be helpful for the economy and society (Becker 2005). However, there is a question about the nature of these "bad laws," and the Russian case perfectly fits those economic theories that look at regulation through the lens of private interests, the view that can also be found in the Austrian scholarship.

Despite the tremendous level of corruption and the usage of regulation in the interests of those who have had access to the regulatory mechanisms, the Russian telecommunications industry has been able to provide a high quality and a big variety of telecommunications services and has one of the best figures of the development of FTTx technology in Europe. The weakness of the state in the initial stages of the analyzed timeline of the industry's evolution provided great opportunities for independent movement to game the system and to perform independently from the plans envisaged by state authorities.

Comparatively low level of concentration of the industry in the fixed markets did not undermine incentives of the industry's actors to invest in the development of their own infrastructure. On the contrary, this forced even the major players to implement new approaches and to increase the quality and availability of services. The successors of the Soviet monopoly, which eventually have been unified under RTK, had no chances to continue to be dominant players using their old copper lines in the places where their competitors developed FTTx infrastructure, and, thereby, were stimulated to carry out modernization. 
However, it is important to note that not all parts of telecommunications in Russia have been able to demonstrate a competitive landscape. And this is not the problem of the attractiveness for investors, high sunk costs or the economies of scale. This is not the consequence of market mechanisms, but the result of the control over development of the industry. The fixed broadband access market, where opportunities for regulatory gaming were comparatively high and the dependence on the business of incumbents was not significant, has shown the lowest level of market concentration in the industry. The rivalry in the market for local telephone services has been remarkable but, nevertheless, limited by the necessity to rely on the conduct of incumbents in the issues of interconnection. The highest concentration in the Russian telecommunications sectors is observed in the market of mobile services, but this is the direct result of state allocation of radio frequencies and not of the genuine market process.

The state institutions of Russia have been becoming stronger, and the consequences of this are not only the growing difficulties in doing business in the country, but also the trends towards concentration of all industries, and the telecommunications are not excepted from this process. The landscape of Russian telecommunications has changed significantly over the last years. The Soviet telecom monopoly has been unified in the single gigantic company in accordance with the initial plans of privatization of the industry. The mobile industry of about the whole country, which previously included many regional players, has been transformed to a field for just four actors with a big probability that this number will decrease further. The fixed broadband market, which in some instances had a low level of concentration, has experienced the significant number of acquisitions over the last years, and, again, there are many reasons to expect that these processes will continue. Nevertheless, the development and the period of the high competitiveness of some parts of the industry in Russia shows that telecommunications in general are really able to have a highly competitive landscape and to allow market mechanisms to play an essential and positive role in the governance of the field.

Acknowledgments The article is based on research conducted by the author within the Erasmus Mundus Joint International Doctoral Programme in Law, Science and Technology. The author is grateful to Ronald Leenes and Pierre Larouche for helpful comments and discussion. The views expressed in the article and any errors are those of the author alone.

Open Access This article is distributed under the terms of the Creative Commons Attribution 4.0 International License (http://creativecommons.org/licenses/by/4.0/), which permits unrestricted use, distribution, and reproduction in any medium, provided you give appropriate credit to the original author(s) and the source, provide a link to the Creative Commons license, and indicate if changes were made.

\section{References}

Anderson GM, Boettke PJ (1993) Perestroika and public choice: the economics of autocratic succession in a rentseeking society. Public Choice 75(2):101-118

Anderson GM, Boettke PJ (1997) Soviet venality: a rent-seeking model of the communist state. Public Choice 93(1-2):37-53

Bauer JM, Bohlin E (2008) From static to dynamic regulation: recent developments in US telecommunications policy. Intereconomics 43(1):38-50

Baumol WJ, Panzar JC, Willig R (1982) Contestable markets and the theory of industry structure. Harcourt Brace Jovanovich, San Diego

Beaulier SA (2010) Without private property, there can be no rational economic calculation. In: Boettke P (ed) Handbook on contemporary Austrian economics. Edward Elgar Publishing, Northhampton 
Becker G (2005) Comment on Corruption-BECKER. Becker-Posner Blog, maintained by the University of Chicago Law School. 28.08.2005. Available at: http://www.becker-posner-blog.com/2005/08/comment-oncorruption-becker.html . Accessed 25 Mar 2019

Beesley ME, Littlechild SC (1989) The regulation of privatized monopolies in the United Kingdom. RAND J Econ 20(3):454-472

Blaug M (2002) Is there really progress in economics? In: Boehm S (ed) Is there progress in economics?: Knowledge, truth and the history of economic thought. Edward Elgar Publishing, Northhampton

Briglauer W, Gugler K (2013) The deployment and penetration of high-speed fiber networks and services: why are EU member states lagging behind? Telecommun Policy 37(10):819-835

Burton J (1997) The competitive order or ordered competition?: the 'UK model' of utility regulation in theory and practice. Public Adm 75(2):157-188

Bychkova O (2002) Rynochnye reformy v rossiyskom sektore telekommunikatsiy: konsolidatsiya reguliruyushchikh funktsiy gosudarstva, 1991-2002 [Market Reforms in Russian Sector of Telecommunications: Consolidation of Regulating Functions of the State, 1991-2002 ]. Econ Soc 4:73-95 (in Russian)

Cambini C, Jiang Y (2009) Broadband investment and regulation: a literature review. Telecommun Policy 33 : 559-574

Cambini C, Silvestri V (2013) Investment sharing in broadband networks. Telecommun Policy 37(10):861-878

Crandall RW, Jeffrey A, Ingraham A (2013) The long-run effects of copper-loop unbundling and the implications for fiber. Telecommun Policy 37(10):262-281

Credit Suisse (2014) Global Wealth Report 2014. CREDIT SUISSE AG. https://www.credit-suisse. com/media/assets/corporate/docs/about-us/research/publications/credit-suisse-global-wealth-report-2014. pdf. Accessed 26 Mar 2019

DiLorenzo TJ (1996) The myth of natural monopoly. Rev Austrian Econ 9(2):43-58

Faulhaber GR (2003) Policy-induced competition: the telecommunications experiments. Inf Econ Policy 15(1): 73-97

Filonov D (2014) Troe na odnogo: pochemu Tele2 ne udalos' stat' chetvertym federalnym operatorom [Three Against One: Why Tele2 did not Manage to Became the Fourth Federal Operator]. Forbes (Russia), July 17, 2014. (in Russian) Available at http://www.forbes.ru/kompanii/internet-telekom-i-media/262895-troe-naodnogo-pochemu-tele2-ne-udalos-stat-chetvertym-fede. Accessed 25 Mar 2019

FTTH Council Europe (2012) Creating a brighter future. Fiber to the home: taking your life to new horizons! Press conference - BBWF Amsterdam, 16 October 2012. http://www.fthcouncil. eu/documents/Presentations/20121016PressConfBBWF.pdf . Accessed 20 Sep 2018

FTTH Council Europe (2016) Graphs September 2015 Market Data. IDATE \& FTTH Council Europe. http://www.ftthcouncil.eu/documents/Reports/2015/2015_RANKING_SLIDES.pdf. Accessed 20 Sep 2018

Gabitov M (2006) Internet v stolize i regionah. Obzor osnovnyh provaiderov shirokopolosnogo dostupa Moskvy. [Internet in the Capital and Regions. Survey of the Main Providers of Moscow]. 3DNews Daily Digital Digest, Dec. 1. (in Russian) http://www.3dnews.ru/188544 . Accessed 15 Sep 2018

GSMA (2013) Universal service fund study conducted on behalf of GSM Association. Report prepared for GSMA by Ladcomm Corporation. https:/www.gsma.com/publicpolicy/wp-content/uploads/2016/09 /GSMA2013_Report_SurveyOfUniversalServiceFunds.pdf. Accessed 25 Mar 2019

Guriev S, Rachinsky A (2005) The role of oligarchs in Russian capitalism. J Econ Perspect 19(1):131-150

Handler M (1973) Regulation versus competition. Antitrust Law J 43:277

Hayek FA (1949a) "Free" enterprise and competitive order. In: Individualism and economic order. Routledge \& Kegan Paul Ltd., London

Hayek FA (1949b) The meaning of competition. In: Individualism and economic order. Routledge \& Kegan Paul Ltd., London

Hill PJ, Karner M (1996) Spontaneous privatization in transition economies. In: The privatization process. Rowman \& Littlefield, London

J'son \& Partners Consulting (2015) Rynok fiksirovannogo shirokopolosnogo dostupa v Rossii v segmente chastnyh pol'zovatelej. Predvaritel'nye itogi 2014 goda [The broadband market in Russia in the segment of private subscribers. Preliminary results of 2014]. (in Russian) Available at http://json.tv/ict_telecom analytics_view/rynok-fiksirovannogo-shirokopolosnogo-dostupa-v-rossii-v-segmente-chastnyhpolzovateley-predvaritelnye-itogi-2014-goda-20150217030011. Accessed 20 Sep 2018

J'son \& Partners Consulting (2017) Osnovnye pokazateli rynka fiksirovannogo SPD v Rossii. Prognoz razvitija do 2025 goda. [The main figures of the broadband market in Russia. Forecast till 2025]. (in Russian) Available at http://json.tv/ict telecom analytics view/osnovnye-pokazateli-rynka-fiksirovannogo-shpd-vrossii-prognoz-razvitiya-do-2025-goda-20170228022714. Accessed 20 Sep 2018

Janson MA, Yoo CS (2013) The wires go to war: the US experiment with government ownership of the telephone system during World War I. Tex L Rev 91:983 
Jordana J, Levi-Faur D, Puig I (2006) The limits of Europeanization: regulatory reforms in the Spanish and Portuguese telecommunications and electricity sectors. Governance 19(3):437-464

Jorde T, Sidak G, Teece D (2000) Innovation, investment and unbundling. Yale J Regul 17(1):1-37

Kirzner IM (2000) The driving force of the market: essays in Austrian economics. Routledge, New York

Kramer DJ (2011) The State of Human Rights and Rule of Law in Russia: U.S. Policy Options. Testimony before the Subcommittee on European Affairs, Committee on Foreign Relations, U.S. Senate, December 14, 2011. http://www.freedomhouse.org/article/state-human-rights-and-rule-law-russia-us-policy-options . Accessed 25 Mar 2019

Kusch I (2008). Zhestokie igry internet provajderov [Violent games of Internet providers], MobiChel.ru, Oct. 30. (in Russian) Available at http://yamobi.ru/posts/jestokie_igryi_internet-provayderov.html . Accessed 15 Sep 2018

Larouche P (2000) Competition law and regulation in European telecommunications. Hart Publishing, Portland

Littlechild S (2018) Regulation and the nature of competition. J Air Transp Manag 67:211-223

Mueller M (2013) Universal service: interconnection, competition, and monopoly in the making of the American telephone system. Syracuse University. Books. http://surface.syr.edu/books/18/ . Accessed 20 Sep 2018

OECD (2015) Organization for Economic Co-operation and Development. Digital Economy Outlook 2015. http://www.oecd.org/internet/oecd-digital-economy-outlook-2015-9789264232440-en.htm . Accessed 20 Sep 2018

Ofcom (2004) Strategic review of telecommunications. Phase 2 consultation document, Nov. 18. Available at http://stakeholders.ofcom.org.uk/binaries/consultations/telecoms_p2/summary/maincondoc.pdf . Accessed 25 Mar 2019

Ostrovsky A (2004) Dinner with the FT: Father to the Oligarchs. Financial Times, Nov. 23

Potresov S (2006) Corbina telecom: Predvaritelnye itogi popytki zahvata moskovskogo rynka shirokopolosnogo dostupa. [Corbina Telecom: Preliminary Results of the Attempts to Capture the Moscow Broadband Market]. (in Russian) Mobile-review.com , Dec. 15, at http://www.mobile-review.com/articles/2006 /corbina-results-2006.shtml. Accessed 20 Sep 2018

Rood H (2010) Very high speed broadband deployment in Europe: The Netherlands and Bulgaria compared. Telecom Policy Research Conference, TPRC, Arlington

RosBusinessConsulting (2002) Obzor otrasli: sotovaya svyaz [Survey of the industry: mobile communications]. (in Russian) Available at http://ecsocman.hse.ru/text/17066473/ . Accessed 25 Mar 2019

Sautet F (2010) The competitive market is a process of entrepreneurial discovery. In: Boettke P (ed) Handbook on contemporary Austrian economics. Edward Elgar Publishing, Northhampton

Serdarević G, Hunt M, Ovington T, Kenny C (2016) Evidence for a ladder of investment in Central and Eastern European countries. Telecommun Policy 40:515-531

Spulber DF, Yoo CS (2013) Antitrust, the Internet, and the economics of networks. U of Penn, Inst for Law \& Econ Research Paper, No. 13-36. Available at SSRN: https://ssrn.com/abstract=2370050. Accessed 25 Mar 2019

Stern J (2003) What the Littlechild report actually said. Regulation Initiative Working Paper. No. 55, 7-30

Stiglitz JE (1999) Promoting competition in telecommunications. Centro de Estudios Economicos de lat Regulacion Working Paper Series

Stiglitz JE (2003) Tax the oligarchs. Project Syndicate, Dec. 7. http://www.project-syndicate. org/commentary/tax-the-oligarchs. Accessed 25 Mar 2019

Trubnikov D (2017) Analysing the impact of regulation on disruptive innovations: the case of wireless technology. J Ind Compet Trade 17(4):399-420

Trubnikov D, Trubnikova E (2010) Institutsionalnye osobennosti infokommunikatsionnoi otrasli RF [Institutional Features of the Infocommunications Industry of the RF]. SNC RAN, Samara. (in Russian)

Trubnikov D, Trubnikova E (2018) Is universal service justified by the public interest? From the early days to the Digital Age. Econ Aff 38:185-196

World Bank (2013) Russian Federation: National and Regional Trends in Regulatory Burden and Corruption. Policy Note, Feb. 2013. Available at http://documents.worldbank.org/curated/en/584111468092953347 /pdf/755690WP0Russi00Box374337B00PUBLIC0.pdf. Accessed 25 Mar 2019

Yoo CS (2011) Deregulation vs. reregulation of telecommunications: a clash of regulatory paradigms. J Corp Law 36(4):847-867

Yoo CS (2014) US vs. European broadband deployment: what do the data say? U of Penn, Inst for Law \& Econ Research Paper, No. 14-35. Available at SSRN: http://ssrn.com/abstract=2510854 . Accessed 25 Mar 2019

Publisher's Note Springer Nature remains neutral with regard to jurisdictional claims in published maps and institutional affiliations. 